Article

\title{
Alliances of Instrumental Advantage: Supporting Women's Agency in Civil Society Organisations in Indonesia
}

\author{
Stephen Sherlock \\ School of Humanities and Social Sciences, University of New South Wales, Canberra, ACT 2612, Australia; \\ E-Mail: stephen.m.sherlock@gmail.com
}

Submitted: 14 June 2020 | Accepted: 7 September 2020 | Published: 25 November 2020

\begin{abstract}
This article examines how Indonesian civil society organisations (CSOs) working for women's empowerment and gender equality have worked together with members of parliament (MPs) to support processes of developmental change. Examples are taken from initiatives supported by MAMPU, an Australian government funded project that promotes gender equality and women's empowerment in Indonesia, describing ways in which gender-focused organisations have engaged with, and had an impact upon, the actions of political leaders in parliament. The article focuses on interaction between institutions and the agency exercised by individuals within institutions. MPs act within a structure of institutional and political incentives, but they also have the power to make choices about how they respond to incentives. Moreover, the leaders of outside actors such as CSOs can modify the structure of incentives by both applying pressure on MPs and providing opportunities for legislators to make different choices. One of MAMPU's tools for targeting MPs has been political economy analysis. Having correctly understood the pressures and incentives facing MPs, CSOs can target their actions to bring about outcomes favourable to both sides in what the article calls 'alliances of instrumental advantage.' Organisations supported by MAMPU achieved success where relationships were forged between the organisations and politicians based on the identification of mutual advantage.
\end{abstract}

\section{Keywords}

civil society organisations; Indonesia; political change; political economy; women's empowerment

\section{Issue}

This article is part of the issue "Leadership and Political Change in Asia-Pacific" edited by David Hudson (University of Birmingham, UK), Nicolas Lemay-Hébert (Australian National University, Australia), Claire Mcloughlin (University of Birmingham, UK) and Chris Roche (La Trobe University, Australia).

(C) 2020 by the author; licensee Cogitatio (Lisbon, Portugal). This article is licensed under a Creative Commons Attribution 4.0 International License (CC BY).

\section{Introduction}

This article examines how Indonesian civil society organisations (CSOs) working for women's empowerment and gender equality have cooperated with members of parliament (MPs) to support developmental change. Examples are taken from initiatives supported by the AustraliaIndonesia Partnership for Gender Equality and Women's Empowerment, known as MAMPU, describing ways in which CSOs partnered with MAMPU have engaged with, and had an impact upon, actions of political leaders in national and regional parliaments. The article focuses on interaction between institutions and the agency exercised by individuals within institutions. MPs act within a structure of institutional and political incentives, but they also have power to make choices about how they respond to those incentives. Moreover, leaders of outside actors such as CSOs can modify the structure of incentives by both applying pressure on MPs and providing opportunities for legislators to make different choices.

MAMPU arose out of a commitment by the Australian government to cooperate with the Indonesian government in reducing poverty. The objective was to help provide a voice for poor women in the developmental agenda to ensure that issues of importance to women were not marginalised in anti-poverty programs (MAMPU, 2019). MAMPU has been implemented in two four-year phases since 2012, receiving funding from the 
Australian Government to a total of about $A \$ 108$ million. The article shows that one of MAMPU's tools for identifying and targeting MPs has been through political economy analysis. In the experience of MAMPU and its partners, having correctly understood the pressures and incentives facing MPs through this analytical process, CSOs can target their actions to bring about outcomes favourable to both sides in what the article calls 'alliances of instrumental advantage.' Organisations supported by MAMPU achieved success where relationships were forged between the organisations and politicians based on the identification of mutual advantage.

Two examples of MAMPU-supported initiatives have been selected. Firstly, intervention in the drafting of laws and regulations on migrant workers, and secondly, facilitation of productive relations between MPs and their constituents. The case studies illustrate how MAMPU and its partners were able to deal with certain challenges - in the first case to bring about changes to a national law that affected the lives of many thousands of Indonesian women (and men), and in the second case to empower local-level women's organisations to exercise influence over their representatives. The ambitions behind these actions were realistic and contextual and should not been seen as a template or definitive model that can be replicated by CSOs in all circumstances. Rather the case studies illustrate what can be achieved when both international donors and CSOs think and work politically to achieve developmental change.

\section{MAMPU and Alliances of Instrumental Advantage}

MAMPU has supported a range of partners to empower low-income women to make use of their political rights, to influence government policies and to demand better services from national and local state institutions. MAMPU has used various approaches to advance these objectives, but an underlying strategy has been to encourage engagement between groups of low-income women, MAMPU's partner organisations, and decisionmaking leaders in both executive government and parliaments. The strategy has been to facilitate engagement with parliamentary representatives as key decisionmakers about matters that affect women's lives, through parliament's roles of passing legislation, deciding on budget allocations, scrutinising executive government actions, and representing the interests of constituents.

MAMPU's methodology for parliamentary engagement has been to enmesh the interests of partner organisations with those of the MPs involved in decisions related to a wide range of issues affecting women. These have included women's access to social protection programs, improved working conditions, women's health and nutrition, reducing violence against women and the rights of migrant workers. The approach has exploited opportunities to identify and focus on common material and political interests of the two sides, especially by using entry points created by incentives influenc- ing the behaviour of MPs. In doing so, this can create the alliances of instrumental advantage between non-state actors and parliamentary leaders mentioned above. They are alliances because they enmesh the interests of forces inside and outside parliament, but they are instrumental in the sense that they are tactical arrangements to encourage reform on specific issues without necessarily having to involve ongoing organisational or ideological agreement.

This approach exemplifies the strategy articulated by Fox (2015) as a 'sandwich strategy' which supports "coordinated coalitions among pro-accountability actors embedded in both state and society" (Fox, 2015, p. 356). In his metanalysis of social accountability initiatives, Fox describes this as a "scenario of mutual empowerment" where "openings from above led by reform champions...meet collective action from below" (2015, p. 356). In the MAMPU-based examples described in this article, reforming stakeholders within institutions were supported by outside actors and, in return, they delivered important outcomes to what Fox calls "their societal counterparts" (2015, p. 356). In one case MPs supported a single legislative change that was central to the objectives of a CSO and, in the other, MPs developed new parliamentary practices that opened opportunities for citizens' input.

\subsection{Indonesian Civil Society and MAMPU}

The decision to initiate a program to strengthen the voice of poor women in Indonesia's poverty alleviation efforts took place in the context of the evolution of CSOs and women's collective action in post-authoritarian Indonesia and of donor efforts to support civil society. During the years of President Suharto, community groups fell under state control and were required to conduct activities under the umbrella of government programs. Thus, women's collective action at the community level virtually disappeared, except for religious groups and the state sponsored Pembinaan Kesejahteraan Keluarga (Family Welfare Guidance). The stifling of more feminist and development focused action has required progressive regeneration since the fall of the Suharto regime in 1998, and external partners, including international donors, have played a role.

Yet even under authoritarian rule, civil society did provide one of the few spaces for political action relatively free from state control-at least at the national level (Aspinall, 2005). Therefore independent CSO activity was able to blossom after 1998 and has "generally been credited with a critical role in turning the country into a functioning democracy" (Mietzner, 2012, p. 217), despite the continuing influence of old elites (Hadiz, 2010; Robison \& Hadiz, 2005). Mietzner has proposed that Indonesia's democracy is "an arena of contestation" between entrenched elites and a range of reformers and that the elites do not always prevail (Mietzner, 2013 c, p. 29). Similarly, Lay $(2017$, p. 2) has argued that 
'a new democratic space' has emerged and, while contested by many actors, this space has provided opportunities for CSOs to assert their agendas in parliament and other locations. It is in these arenas of contestation that CSOs continue to exercise influence over decisions about policies, laws and practices by state institutions and powerbrokers. And such arenas have been the site of MAMPU-supported actions by civil society.

But the picture still remains mixed. Perdana (2015) documented many of the democratic reform achievements of CSOs after 1998 but highlighted that civil society as a whole has been weakened by internal fragmentation and by continuing patronage-based politics. Reflecting such concerns, recent years have seen a tone of pessimism enter debate about Indonesian democracy and the power of civil society (Mietzner, 2020; Warburton \& Aspinall, 2019). Nevertheless, CSOs remain active and considerable advances have been made in the creation of spaces for collective action amongst previously marginalised groups such as women (Migunani, 2017). This is especially so at the regional level, where women had previously been excluded from public debate, but where possibilities were opened up by reforms that devolved many areas of government authority to the districts from 2001.

MAMPU engages with women's and gender equality focused CSOs from the angle of building alliances to ensure that voices of poor women are on the agenda of poverty alleviation. MAMPU was not specifically designed for reform of democratic structures but rather with the aim of empowering a marginalised group to participate in processes of decision-making available in a democracy. As such, it is an inherently political undertaking because it requires CSOs and the groups they work with to enter the arenas of political contestation described above. But MAMPU does not engage directly with state institutions, nor is it simply a CSO-strengthening exerciseMAMPU attempts to work at the point of interaction between the state and its citizens by supporting Fox's "pro-accountability stakeholders" and their "scenarios of mutual empowerment" (Fox, 2015, p. 356).

\subsection{Role of Political Economy Analysis}

Since MAMPU's approach is deeply political, it requires a keen understanding of the written and unwritten rules of politics. The role of political economy analysis in the MAMPU methodology is to dissect the roles and relationships shaping the behaviour of parliamentary representatives in order to understand how the world appears from their perspective and thus how they might, or might not, respond to particular approaches from non-state actors. The analysis of the structure of incentives facing MPs provides a conceptual tool which, when applied to a specific issue and specific set of MPs, provides a guide for action.

As suggested above, political economy analysis starts from the proposition that political systems give rise to an array of incentives that influence the behaviour of actors within the system. Political actors in any institutional framework will use incentives created by that framework to maximise advantage for themselves. And powerful actors usually have a good understanding of how to gain advantage because, firstly, they benefit from mentorship and direction from their leaders and, secondly, because they develop their own personal experience and expertise from working within the system. Outsiders, however, benefit from neither of these advantages and may have little knowledge of formal mechanisms and limited grasp of informal practices and unspoken rules followed by insiders. For actors such as CSOs, an added impediment can be distaste for what they see as the 'dirty game' of politics and a sense that becoming adept in political manoeuvring might somehow sully their character. But thinking and acting politically is critical to the success of CSOs because not knowing the written and unwritten rules of the game, or deliberately shrinking from gaining such knowledge, places them at a great disadvantage. Understanding the incentives influencing the behaviour of insiders is a central component in empowerment of outside actors.

Political economy analysis can therefore be used as a tool by less powerful political actors to create alliances with insiders within state institutions and thereby influence insiders' decision-making. Such analysis can provide insights into pressures that influence the actions of insiders and support the development of strategies that are most likely to illicit positive responses to ideas and proposals from outsider organisations. The MAMPU methodology uses analysis of the institutional and stakeholder variables of the political economy of Indonesia's parliaments and how they affect the behaviour of MPs. The focus is on MPs as individual actors because, as in any institution, it is the behaviour of people that occupy positions in parliament that determine its character. A purely institution-focused approach tells us something about what the rules are, but sheds less light on the reasons actors within an institution behave the way they do. We need to know not only what institutional actors do, but why they do it.

The political economy approach has a long pedigree is social science, but it has been taken up more widely in international development circles in recent years. The most notable examples are frameworks formulated by the World Bank (Fritz, Kaiser, \& Levy, 2009) and the Drivers of Change approach developed by the UK Department of International Development (Warrener, 2004). MAMPU's use of political economy analysis has developed in the context of debates about the practical utility of such analysis. Hout takes the view that while donors are "concerned about the political context in which they operate, they feel they should not themselves be concerned with politics in their partner countries" (Hout, 2012, p. 407), emphasis in original). Being foreign development agencies, Hout contends that they "experience an almost insurmountable difficulty" (2012, p. 407) 
in integrating their analysis into programs because of the risk of political meddling in a sovereign country. This has created a tendency for donors to take the politically more tenable approach of concentrating on technical matters because they are not in a position to openly confront entrenched interests. But while MAMPU is not designed to encourage head-on engagements with existing power elites, it is still a political endeavour. As outlined above, it provides support for bringing together reforming elements within society and within decision-making institutions in order to create coalitions with potential to bring about change.

MAMPU's political economy analysis concentrates on the dynamic interaction between institutional variables such as legislation, rules and organisations and actor/stakeholder level variables such as societal actors, political leaders, interest groups and individual actors (Warrener, 2004, p. 8). In the arena of parliamentary engagement, the focus is on how institutional incentives inside and outside parliament interact with individual parliamentary actors. In analysing the interaction, it reveals that MPs are not merely passive reflections of incentives they confront, but actively respond to them to achieve personal and collective objectives. At the same time, MPs are also constrained by these influences and can even be forced to act in ways that they would prefer not to, and which may even go against their own personal values. But it should always be remembered that the way individual actors choose to respond to the pressures of their political environment will vary in degree and kind. For example, all MPs need to keep potential financial supporters friendly to them, but some will try to balance donors' influence against the best interest of their constituents, while others may subordinate themselves to wealthy donors or even corruptly collude for personal gain.

I am not suggesting that all MAMPU initiatives have been preceded by formal political economy analysis, but rather that the program has learnt through practice that the best outcomes were achieved when they implicitly or explicitly built on an intersection of interests between the two sides. Recognition of the efficacy of this approach has motivated MAMPU's efforts to integrate the approach more explicitly into programming. MAMPU therefore engaged the author of this article to, firstly, conduct a political economy analysis of incentives that influence the behaviour of MPs and, secondly, to review previous efforts in parliamentary engagement by MAMPU and its partners. The review tracked the evolution of MAMPU's engagement and determined that the most effective examples of engagement were politically informed and were responsive to changing political context. The review drew lessons to be passed on to MAMPU partners in the form of advice and guidelines for their future activities. Nevertheless, it should be emphasised that in the two examples to be discussed below, the organisations supported by MAMPU conducted studies of the various stakeholders involved that were very sim- ilar to political economy analyses and which had similar effect. In one case, the organisation carried out "actor mapping" (Arus \& Ghofur, 2015, pp. 12-15) based on the essential principles of political economy analysis and, in the other, the organisation developed guidelines for participants that included elements of the methodology (Yayasan BaKTI, 2019).

\subsection{What Incentives Influence the Actions of Indonesian Member of Parliament?}

This section analyses the structure of incentives that influence the behaviour of Indonesian MPs and describes the relationships from which the incentives emanate. It is important to reiterate from the outset that the relationship between incentives and behaviour is not simply deterministic-legislators have agency and they make their own decisions about how to act. But every day of their political lives they are forced to react in some way to pressures bearing upon them. And understanding these pressures helps to make sense of patterns in politicians' behaviour and why certain approaches from the outside are likely to receive a positive response and others are not.

Indonesia has a presidential system where the separation of powers between the executive and legislative branches of government endows parliament with extensive political authority. There are parliaments at both the national level and regional levels, and both routinely use their independent popular mandate to play a role in drafting and passing laws, including state budgets, and have potentially formidable powers to hold the executive to account (Sherlock, 2007). Members of these parliaments play different roles as election candidates, political fundraisers, party members, constituent representatives, members of parliamentary committees and partners/protagonists of executive government. The network of relationships is illustrated in Figure 1.

\subsubsection{MPs as Election Candidates}

The cost of campaigning has escalated dramatically during the last several Indonesian elections, a trend that most observers see as a result of the 'open list' electoral system which permits voters to vote for either individual candidates or a party. The system has created perverse incentives for candidates and entrenched what is locally known as 'money politics,' such as vote-buying and porkbarrelling. Recent in-depth research studies throughout Indonesia, observed that the system is "widely blamed by political candidates and voters alike for increasing pressures for patronage" (Aspinall \& Sukmajati, 2016, p. 5). One former MP observed that elections have become more "capital intensive" and without significant financial backing it is "not realistic to run" (personal communication, 2018). Campaigns increasingly appear to be like auctions where candidates try to prove they can bring voters higher material benefits. One candidate 


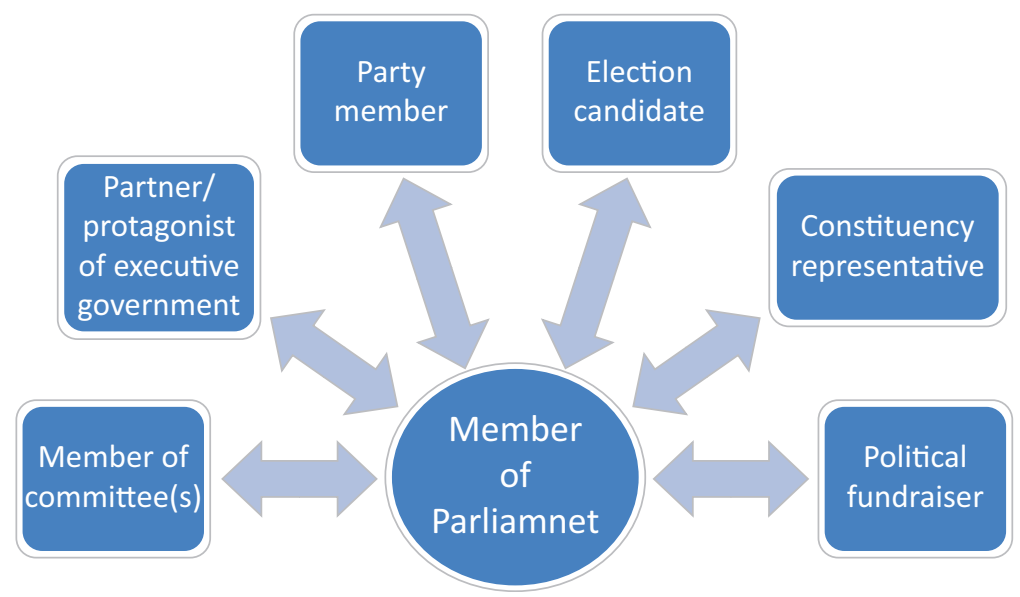

Figure 1. Relationships in MPs structure of incentives.

complained that it is "a real struggle to get people to vote for you on the basis of ideas, rather than...gifts of money or goods" (Aspinall \& Sukmajati, 2016, p. 63). The incentive is to offer handouts rather than to advocate policy or ideals. The challenge for all CSOs and other outsiders is to find ways of influencing public attitudes about the meaning of elections. I have frequently interviewed women candidates who have expressed frustration at the problem of finding a supportive community environment in which to put forward ideas and proposals about issues affecting women.

\subsubsection{MPs as Fundraisers}

In such circumstances, politicians have to be fundraisers. Patronage and clientelism have been longstanding features of Indonesian society and politics, but modern, urbanising, commercialised and media-based cultures have entrenched new forms of clientelism (Magaloni, 2014), rather than eliminating them as once was expected (Aspinall, 2013; Brun \& Diamond, 2014). Political costs do not end after election day because an MP must maintain his/her profile and popularity after winning an election. A clientelist political culture creates expectations that parliamentary patrons will personally provide benefits to a community. Brun and Diamond (2014, p. 257) emphasise that in many developing countries "politicians need to mobilise votes through the distribution of particularist benefits or clientelistic promises rather promises of public goods." MPs are locked into clientelist relationships if they want to be re-elected.

There is thus a strong incentive for politicians to seek out wealthy donors and to enter into relationships involving influence-buying, rent-seeking and corruption. For example, collusive arrangements develop where companies win contracts as a result of their connections with MPs. The ever-increasing cost of politics has meant that elected positions are increasingly being filled by businesspeople or individuals supported by them (Mietzner, 2007). This generates a self-reinforcing nexus between MPs who are attracted to rent-seeking behaviour as a method of staying in office and those who are attracted to public office because of opportunities for enrichment. For women's organisations, who have no financial resources to offer, the task is to find other forms of support for sympathetic representatives and to thus increase the possibility that such MPs can sustain a viable career in public life without falling into the grip of transactional politics.

\subsubsection{MPs as Party Members}

Indonesian parliamentarians' role as party representatives creates a particular set of incentives and obligations. Firstly, legislation obliges candidates to be nominated by a party, and a high-ranking position on the party ticket is a crucial advantage. And since Indonesia's parties tend to be dominated by small cliques of leaders, MPs are obliged to stay close to those leaders and win favour with them. Good party relationships come at a cost-parties demand substantial payments for a top position on the party ticket and expect ongoing contributions (Mietzner, 2013a, 2013b). The most influential MPs are those with deep pockets and connections with influential local and national families. One corollary of the transactional nature of relations between MPs and their parties is that central party machines rarely exercise discipline over their members when it comes to policy matters. The parties are weak on policy development (Mietzner, 2013b) and, while they expect MPs to defend the material interests of the party in patronage-based politics, they rarely intervene in policy and legislative debates unless the direct personal interests of party leaders are at stake. I have shown elsewhere (Sherlock, 2012) that the policy-making function usually ascribed to political parties in political science literature has, in Indonesia, largely been subsumed by the parliamentary committee system. Policy proposals are mostly the product of initiative by small numbers of committee members, usually with little reference to an official party stance (Sherlock, 2009).

Paradoxically, this weakness in parties provides openings for CSOs to build bridges with parliamentary figures 
seeking practical support to intervene as issues emerge onto the political stage. MPs with ambitions to enhance their profile by developing expertise and connections in a particular policy area need to seek outside assistance because they are unlikely to find backing within the party machine. Thus, openings for CSOs frequently arise during the course of parliamentary deliberations on legislation, but CSOs must be well-informed about potential partners and well-attuned to the ebb and flow of political life in order to exploit the advantage. A key aspect of that process is to realise that prominent players rarely act under party direction but are mostly driven by individual ambition and internal political dynamics within their committee.

\subsubsection{MPs as Parliamentary Committee Members}

Because of the extensive power of the legislature in Indonesia's presidential system, parliamentary committees are key centres of decision-making. Therefore, one of the most powerful incentives for an MP is to be active in committee roles in order to exercise influence and build networks of power and patronage. In particular, leadership positions such as committee chair or deputy chair are highly sought after. For members with ambitions to become leading national or regional political figures, prominent committee roles can be a steppingstone to power, including as a powerbroker inside their party. This makes committees involving large government budgets, such as education or infrastructure, attractive for rent-seeking opportunities. But other more policy-driven committees, such as foreign or legal affairs, provide openings for MPs building a reputation for strategic thinking. In regional parliaments, committees are responsible for overseeing budget allocations for the provision of services in areas such as community health, education, local infrastructure and issues about the quality of service delivery. The importance of the committee system in parliamentary decision-making makes it a key target for women's organisations. But, once again, outside interventions must be properly timed and carefully calibrated to the needs of inside actors who may be willing to cooperate. Issues come and go, and the attention span of parliamentary committee members is short.

\subsubsection{MPs as Partners or Protagonists of Executive Government}

MPs have strong incentives to build a reputation in their dealings with executive government and to maintain a network of connections with ministers and senior officials. This can be achieved by being seen as a cooperative partner who is known for his/her policy expertise or by building a profile as a protagonist of government who, for example, asks difficult questions during committee investigations. Having respect in government circles enables MPs to obtain information and to facilitate both formal and informal meetings connected with their committee or party work. Stand-offs and other interactions between legislative and executive government actors have repeatedly opened up opportunities for CSOs to exercise influence by cooperating with strategically identified MPs. An example was the case discussed below where Migrant CARE provided data, arguments and drafting assistance to MPs who were arguing their case with executive government agencies about legislation on migrant workers.

\subsubsection{MPs as Constituency Representatives}

Finally, of course, MPs are elected as representatives of a particular constituency. This can be the most difficult role because incentives to be a good constituency representative are in competition with other pressures. As mentioned, there are strong pressures to win elections and stay in office through embedding oneself in the culture and practices of transactional politics. The relatively weak capacity of the Indonesian state to deliver policy and/or programmatically based public goods creates pressures on legislators to be seen as using their personal influence to win special benefits for individuals and narrowly targeted groups (Keefer, 2007). And citizens' approaches to parliamentarians for direct assistance are highly rational in an environment of weak government services. Indeed, this can discourage MPs from engaging broadly with their constituents because they want to avoid constant demands for help. Nevertheless, as the case study of the CSO BaKTI outlined below indicates, it is possible for women's organisations to facilitate a better quality of interaction between MPs and their constituents and, in doing so, to provide stronger incentives for political representatives to go out into the community.

\subsection{Case Studies}

Let us now examine two cases of CSO engagement with parliaments by MAMPU partner organisations which exemplify the effectiveness of approaches which enmesh the interests of outside organisations and parliamentary actors. The cases are, firstly, the success of Migrant CARE in influencing the content of legislation on Indonesian migrant workers and, secondly, initiatives led by BaKTI which have shown potential to develop more productive relations between MPs and their constituents.

\subsubsection{Migrant CARE}

To take the first case, Migrant CARE is an advocacy and support organisation whose goal is to argue for legislative and other protections for overseas Indonesian workers and their families and to provide legal and other assistance to ensure they understand "their rights as workers and citizens" (Migrant CARE, 2016) and that their time abroad is lived with dignity and respect. The treatment of Indonesian migrant workers, including bad working conditions, low pay, withholding of wages 
and physical and sexual abuse, has been a prominent issue for many years. Humanitarian concerns and feelings of national outrage were generated by horrific stories of individual cases and personal tragedies. MAMPU partnered with Migrant CARE because a large proportion of Indonesian migrant workers are women and because women workers are most vulnerable to exploitation and abuse. For its part, Migrant CARE recognised that the issue of migrant workers' rights is highly gendered and that bringing about change had to involve active support from women workers.

Following the inauguration of a new national parliament in 2014, Migrant CARE began lobbying for amendments to legislation on overseas workers. Crucially, the organisation developed a good relationship with the chair of the committee responsible for the bill, who was supportive of legislative reform. They also cultivated links with other committee members and their staff, leading party figures and specialist staff inside parliament, and worked together on drafting new legislation. Interaction with parliament took many forms, including formal meetings and drafting sessions, appearances before parliamentary committees, public events, media conferences, and informal meetings with individual MPs in cafes, homes and offices. Migrant CARE was closely associated with every stage of drafting and deliberations on the legislation and their efforts were rewarded with the passage of a law in 2017 that incorporated most of the proposals they had put forward.

Migrant CARE's input was highly regarded by leading committee members because it provided extensive data about the issue and practical proposals for key problems, such as proposed wording for key clauses of the bill. In particular, Migrant CARE's ability to bring women who had experienced abuse as migrant workers to appear in person and tell their stories to parliamentary meetings was invaluable in breaking down resistance to reform. This was an example of what one MP said a committee valued from CSOs: "Something we can work with," rather than aggressive hectoring and grandstanding (personal communication, September 2018). In the words of the committee chair:

If you hold a demo, it's just a demo, a way to say something in public. But if a small number comes to me and we have a discussion, there can be some result. There can be mutual benefit for you and me. (Personal communication, May 2018)

Migrant CARE was able to make well-timed and targeted interventions at specific stages of deliberations because the organisation was closely attuned to the politics of the process-for example, suggesting compromise solutions when the committee was deadlocked. This was in contrast to what another MP identified as some CSOs' tendency to simply repeat a standard set of arguments and to show themselves unfamiliar with both the technicalities and the politics of deliberations (personal communi- cation, September 2018). In return, the view of the committee chair was that civil society had "got most of what they wanted" in the final version of the legislation (personal communication, September 2018).

Migrant CARE's work on this legislation could have remained a one-off achievement at the national level, but MAMPU worked with the organisation to encourage it to extend its methodology to Indonesia's regions, with the aim of influencing the passage of regional legislation in migrant-sending provinces. For example in early 2015 , the organisation cooperated with a multistakeholder network in the provinces of Nusa Tenggara Timur and Nusa Tenggara Barat to develop draft legislation on migrant workers and their families in three districts in the provinces. By the middle of the year, drafts had been accepted by two of the three relevant district legislatures and were eventually passed into law.

Migrant CARE's initiatives succeeded where they enmeshed with the interests of leading parliamentary figures in pivotal positions-principally the chair of the responsible committee and supportive members-and helped them to respond to the array of incentives identified above. Firstly, the organisation's backing for the passage of good quality law supported MPs in their roles as both committee members and party members because it demonstrated the MPs' effectiveness as leading political operators who could make an impact in policy terms. Policy units in Indonesian political parties are generally weak, thus throwing a burden of policymaking responsibility onto parliamentary committees that they are ill-equipped to handle (Sherlock, 2010, 2012). Partly through Migrant CARE's assistance, committee members could take credit for improving the public standing of the parliament and their respective parties, in the face of frequent criticism of the quantity and quality of legislative output. This was an especially potent outcome for the committee leadership because stories of abuse of Indonesians overseas had struck an angry response amongst the public. Secondly, passage of the law enhanced the relationship between committee members and executive government powerbrokers, because final agreement on many clauses of the legislation was only reached after hard negotiations with government agencies which had competing ideas about the objectives of the law. Finally, for committee members representing constituencies with migrant workers, passage of the law was extremely valuable for their efforts to be seen as responding to constituents' concerns.

\subsubsection{BaKTI}

In the second case, BaKTI-an umbrella organisation with affiliate groups in eastern Indonesia-has led efforts to facilitate better interaction between MPs and women's organisations in their communities and to overcome problems created by perverse incentives discussed above. The increasing centrality of 'money politics' can crowd out incentives for MPs to engage with constituents 
on local issues, policies and the provision of public goods. If voters see their MPs only as providers of private benefits, then politicians are discouraged from even visiting their constituencies, except to promise things during election time. In an attempt to address this problem, national and regional parliaments created rules obliging (and financing) MPs to visit their constituencies during parliamentary recess periods, thus aiming to manufacture a regulatory incentive to counteract incentives created by the prevailing transactional political culture. The practical result, however, was that MPs conducted formal ritualistic meetings with hand-picked groups of well-connected constituents who attended only to listen passively to speeches and to pocket attendance money.

It was these realities that BaKTI observed as it worked with MAMPU on a range of initiatives to promote parliamentary engagement by low-income women. Since 2012 , the organisation has worked to turn conventional top-down parliamentary recess events on their head by a new approach called 'participative recess.' Under this strategy, public discussions between constituents and MPs take previously formalistic proceedings and turn them into active participatory events. The objective is to bring issues affecting women to the attention of local MPs. There are few speeches and the bulk of the time is devoted to organising participants into focus group discussions based around issues of importance to them. Each group formulates a set of issues to present to the MP at a plenary discussion with the promise that the MP will take up the issues in parliament and with relevant government agencies.

The basis of the method is to build coalitions between community-based women's organisations and MPs who are looking to break the stranglehold of transactional politics. BaKTI organises what it calls 'constituent groups' which are composed of local groups and individuals, but which receive formal endorsement through a written agreement with MPs and local government. These agreements ensure that the participative recess activities receive support from the local parliamentary secretariat in the form of logistics, venues and funding. BaKTI makes particular effort to attract the widest possible membership and that group leaders are composed of committed people and not co-opted by local powerbrokers. The number of MPs involved is still limited and the methodology represents only a beginning, but it is a model for what could be done if larger and more powerful players were to take up the idea.

The strength of the participative recess initiative lies in its potential to tap into the most basic of incentives for MPs - to promote their standing in communities and to retain office in the next election. The constituent groups and the meetings they sponsor help MPs to get a better understanding of what voters are experiencing and thinking. In the face of powerful incentives to relate to voters only in terms of individual monetary benefit, the initiative provides openings for MPs to engage with constituents on a broad range of issues related to delivery of government services and provision of public goods. This is the reason the approach has been taken up and actively driven by some politicians themselves-they have replicated the BaKTI methodology and independently built connections beyond community groups around BaKTI. Such MPs are pushing against the dominant stream of transactional politics, but they show that there is a cohort of politicians who genuinely want to build better constituent relationships. It is MPs such as these that receive encouragement and practical support from participative recess activities. There is then potential for MPs with respect in the community and increased prospects for reelection to respond to one of the other main pressures that bear upon them-to build their profile and reputation within their respective parties and, by doing so, to positively influence the behaviour of their peers.

\section{Conclusion: Thinking Politically}

The formation of coalitions of instrumental advantage supported by MAMPU is fundamentally a matter of taking developmental reform beyond the merely technical into the realm of the political. Relatively powerless groups in society such as low-income women can advance their interests if they reach an understanding of the written and unwritten rules that govern decision-making institutions and the behaviour of political leaders, and then learn how to make political systems operate in their favour. The experience of the MAMPU program, and its partners such as Migrant CARE and BaKTI, highlights a number of key conclusions.

Firstly, the structure of incentives that influence MPs' behaviour should not be read in a deterministic or static fashion. In Indonesian circumstances, political economy analysis could lead to the pessimistic conclusion that all politicians are driven by forces of 'money politics,' to the exclusion of what civil society might see as good representation. But politicians also have agency-they must respond to pressures around them, but they make choices about how they respond. Moreover, outside actors have agency as well and are participants in making and remaking incentives that leaders confront. For example, when Migrant CARE built supportive relationships with MPs advocating legislative reform they changed the structure of incentives in a positive way by increasing the power of forces outside parliament working in favour of change-had there been no civil society voice reformers may well have capitulated to opponents of change. Similarly, the participative recess methodology is a way to mobilise community voices in support of MPs pushing to make elected representatives more accountable to constituents. In doing so, they tilt the balance of incentives away from a predominance of clientelist relationships and strengthen incentives for representatives to be responsive to the community.

Secondly, the nature of alliances of instrumental advantage, as distinct from lasting compacts based on a common political philosophy, is that they are fluid, 
tactical and contextual. The fact that MPs have agency and make decisions about their behaviour also means that their responses are also highly contextual and that alliances with them are time-bound. MPs' actions can vary greatly according to the issue and its timing within political and electoral cycles.

On some issues at certain times they may be willing to work together with an outside organisation, but on others they may not return its calls. Such an understanding is important when CSOs try to identify possible entry points into a parliament and who are likely to be partners or champions. There is a tendency for development advocates to give the impression that there will necessarily be a recognisable bloc of dependable 'reformers' who can be relied on for consistent support. While the existence of such a bloc would clearly be ideal, the reality is that political figures are likely to be inconsistent. Of course, it is sensible to aim for lasting long-term alliances when more principled agreement with a committed champion is possible, but this cannot be expected in most cases. Thus, it is generally more productive to follow Migrant CARE's practice and map out who may be willing to cooperate on the basis of mutual advantage on a particular issue at a specific time.

The identification of champions in the Indonesian context is especially difficult because, as discussed above, parties generally lack a consistent policy orientation and it is very difficult to predict what stance any particular MP might take on the basis of their party affiliation. MPs with clear policy commitments must normally be pinpointed individually because, without really intending to, parties have given their MPs more individual agency than would be expected in a parliament where members are subject to strict policy discipline. For example, Migrant CARE's experience was that all parties debating protection of migrant workers were united in condemning abuse of Indonesians overseas, but beyond a common reflexive nationalistic response, the stances of key individuals in the responsible committee bore little relationship to their party background. Similarly, BaKTI has identified no consistent correlation between MPs' party affiliations and their willingness to commit to the participative recess process and does not ever expect to do so (personal communication, March 2018).

It can be useful to think in terms of three likely cohorts amongst decision-makers on any issue: Obvious advocates, clear opponents and the-probably largestgrouping of 'undecideds' that can be swayed by developments. Parliaments and parliamentary committees will usually have a cohort of the first kind who are known to be motivated by a policy interest or a thought-out political philosophy or ideology, but they will regrettably be small in number and should not be the exclusive focus of attention. The second cohort of committed opponents would clearly not be productive targets. The third non-committal cohort, on the other hand, will usually include individuals who could possibly be brought on side because of particular interests related to the issue at hand. Reformers can emerge from the most surprising places. But the number of close working partners is likely to eventually centre on a core group of individuals, after an initial period of surveying all possible openings. All MPs should be targets for general publicity and argumentation, but allies and champions will be few.

Of course, all potential relationships with parliamentary cohorts need to be subject to a careful risk assessment. There may be political risks in working with a particular individual or group of MPs who have a wider political or ideological agenda. There may be reputational risks of being seen associating with someone who is later revealed to have been involved in unethical or illegal behaviour. Political relationships are based on mutual advantage, but while identifying potential partnerships, it is also important to assess the risk of being exploited, or of unintended consequences from being associated with negative views or practices.

Finally, it is imperative that outsider organisations bring something politically valuable to potential partners in parliament. Thinking politically means knowing what is appropriate and what is timely. Migrant CARE provided support to reform champions to help them win a political battle and was rewarded with a greatly improved legislative framework. BaKTI has provided a framework and inspiration for MPs who want a more genuine interaction with their constituents and have consequently strengthened the voice of marginalised sections of the community. The key lessons are that trust and engagement take time and require politically-informed analysis to connect with the right partners, and that strategic interventions in concert with leading decision-makers can pay dividends. The experience of MAMPU and its partners, as exemplified by the two cases discussed in this article, is that although parliamentary politics in Indonesia has many problems, there are still openings for engagement that can actually change the structure of incentives facing MPs for the better. Realising that political relationships are inherently opportunistic and often impermanent provides a foundation for clear-headed thinking about what is politically possible at any given time.

\section{Acknowledgments}

The author wishes to acknowledge the support of the MAMPU program in the conduct of my research for this article, and the valuable inputs from two anonymous reviewers.

\section{Conflict of Interests}

The author declares no conflict of interests.

\section{References}

Arus, Y., \& Ghofur, A. (2015). Placing migrant worker issues on Indonesia's national legislative agenda. Yogyakarta: Circle Indonesia. 
Aspinall, E. (2005). Opposing Suharto: Compromise, resistance and regime change in Indonesia. Stanford, CA: Stanford University Press.

Aspinall, E. (2013). A nation in fragments: Patronage and neoliberalism in contemporary Indonesia. Critical Asian Studies, 45(1), 27-54.

Aspinall, E., \& Sukmajati, M. (2016). Electoral dynamics in Indonesia: Money politics, patronage and clientelism at the grassroots. Singapore: NUS Press.

Brun, D. A., \& Diamond, L. (Eds.). (2014). Political clientelism, social policies, and the quality of democracy. Baltimore, MD: Johns Hopkins University Press.

Fox, J. (2015). Social accountability: What does the evidence really say? World Development, 72, 346-361.

Fritz, V., Kaiser, K., \& Levy, B. (2009). Problem-driven governance and political economy analysis: Good practice framework. Open Knowledge Repository. Retrieved from https://openknowledge.worldbank. org/handle/10986/16777

Hadiz, V. (2010). Localising power in post-authoritarian Indonesia: A Southeast Asia perspective. Stanford, CA: Stanford University Press.

Hout, W. (2012). The anti-politics of development: Donor agencies and the political economy of governance. Third World Quarterly, 33(3), 405-422.

Keefer, P. (2007). Clientelism, credibility and the policy choices of young democracies. American Journal of Political Science, 51(4), 804-821.

Lay, C. (2017). The emerging of new democratic space: CSOs and parliament in post-Soeharto Indonesia. PCD Journal, 5(1), 1-24.

Magaloni, B. (2014). Defining political clientelism's persistence. In D. A. Brun \& L. Diamond (Eds.), Clientelism, social policies, and the quality of democracy (pp. 253-262). Baltimore, MD: Johns Hopkins University Press.

MAMPU. (2019). The MAMPU performance story: 20122018. Jakarta: Australia-Indonesia Partnership for Gender Equality and Women's Empowerment.

Mietzner, M. (2007). Party financing in post-Soeharto Indonesia: Between state subsidies and political corruption. Contemporary Southeast Asia, 29(2), 238-263.

Mietzner, M. (2012). Indonesia's democratic stagnation: Anti-reformist elites and resilient civil society. Democratization, 19(2), 209-229.

Mietzner, M. (2013a). Political party financing in Indonesia is a recipe for corruption. Strategic Review. Retrieved from http://www.sr-indonesia.com/in_ the journal/view/political-party-financing-in- indonesia-is-a-recipe-for-corruption?pg=2

Mietzner, M. (2013b). Money, power and ideology: Political parties in post-authoritarian Indonesia. Singapore: NUS Press.

Mietzner, M. (2013c). Fighting the hellhounds: Prodemocracy activists and party politics in post-Suharto Indonesia. Journal of Contemporary Asia, 43(1), 28-50.

Mietzner, M. (2020). Sources of resistance to democratic decline: Indonesian civil society and its trials. Democratization. https://doi.org/10.1080/13510347.2020. 1796649

Migrant CARE. (2016). Visi \& missi [Vision \& mission]. Migrant CARE. Retrieved from https://migrantcare. net/profil/visi-misi

Migunani. (2017). Women's collective action for empowerment in Indonesia: A study of collective action initiated by partners of the MAMPU program. Yogyakarta: Migunani and MAMPU.

Perdana, A. (2015). The politics of civil society organizations (CSOs) post-reformation 1998. Masyarakat: Jurnal Sosiologi, 20(1), 23-42.

Robison, R., \& Hadiz, V. (2005). Reorganising power in Indonesia: The politics of oligarchy in an age of markets. London: Routledge.

Sherlock, S. (2007). The Indonesian parliament after two elections: What has really changed? (Policy Paper No. 2), Canberra: Centre for Democratic Institutions.

Sherlock, S. (2009). Parties and decision-making in the Indonesian parliament: The case of the anti-pornography bill. Australian Journal of Asian Law, 10(2). https://www.federationpress.com.au/ journals/abstract.asp?id=315

Sherlock, S. (2010). People's forum or chamber of cronies? The parliament in Indonesia's decade of democracy. In E. Aspinall \& M. Mietzner (Eds.), Problems of democratisation in Indonesia (pp. 160-180). Singapore: ISEAS.

Sherlock, S. (2012). Made by consensus and committee: Parties and policy in the Indonesian parliament. Southeast Asia Research, 20(4), 551-568.

Warburton, E., \& Aspinall, E. (2019). Explaining Indonesia's democratic regression: Structure, agency and popular opinion. Contemporary Southeast Asia, 41(2), 255-285.

Warrener, D. (2004). The drivers of change approach. London: Overseas Development Institute.

Yayasan BaKTI. (2019). Panduan reses partisipatif [Guide to the participative recess]. Makassar: Yayasan BaKTI and MAMPU.

\section{About the Author}

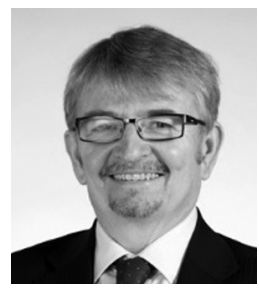

Stephen Sherlock is Adjunct Associate Professor at the University of New South Wales, Canberra. His research interests include parliaments, political parties, political governance and women's representation in Indonesia. He is former Director, Centre for Democratic Institutions, Australian National University, and is currently an Independent Consultant in Indonesia, Southeast Asia and the South Pacific. 